\title{
Pelatihan Pembuatan Diagram dengan Microsoft Excel di SMP Mainang Kabupaten Alor
}

\author{
Narita Yuri Adrianingsih ${ }^{1 *}$, Jeni Marianti Loban ${ }^{2}$, Landerius Maro ${ }^{3}$, Lory \\ Fitriana Ur Dollu 4 \\ 1,2,3,4 Universitas Tribuana Kalabahi, Alor, Indonesia \\ *Corresponding Author: naritayuria98@gmail.com
}

\begin{abstract}
Info Artikel
Diterima: $17 / 02 / 2022$

Direvisi: 20/02/2022

Disetujui: 22/02/2022

Abstract. Diagram making training using Microsoft Excel is a community service carried out at the Toyg State Junior High School, which is in the Toyg Village, Alor Regency. This activity was carried out for 1 day during the training. This training aims to make students understand how to present diagrams using Microsoft Excel. The material provided has been prepared before the training, namely regarding the presentation of data with diagrams in the statistics subject. The method used is presentation and then direct practice is carried out by students. The obstacle at school is that there are no computer facilities so this is a new thing for them and they are very enthusiastic about participating in this training, so that the children quickly understand what they are being trained to do.
\end{abstract}

Keywords: Diagram, Training, Microsoft Excel

Abstrak. Pelatihan pembuatan diagram dengan menggunakan Microsoft Excel merupakan pengabdian masyarakat yang dilaksanakan di SMP Negeri Mainang, yang ada di Desa Mainang, Kabupaten Alor. Kegiatan ini dilakukan selama 1 hari pada saat pelatihan. Pelatihan ini bertujuan supaya siswa/i bisa mengerti bagaimana cara menyajikan diagram dengan menggunakan Microsoft Excel. Materi yang diberikan telah dipersiapkan sebelum pelatihan yaitu mengenai penyajian data dengan diagram yang ada di mata pelajaran statistika. Adapun metode yang dilakukan dengan presentasi kemudian dilakukan praktek langsung yang dilakukan oleh siswa/i. Hambatannya di sekolah tidak ada fasilitas komputer sehingga hal ini merupakan hal baru bagi mereka dan mereka pun sangat antusias mengikuti pelatihan ini, sehingga anakanak cepat mengerti akan apa yang dilatihkan kepada mereka.

Kata Kunci: Diagram, Pelatihan, Microsoft Excel.

How to Cite: Adrianingsih, N. Y., Loban, J. M., Maro, M., \& Dollu, L. F. U. (2022). Pelatihan Pembuatan Diagram dengan Microsoft Excel di SMP Mainang Kabupaten Alor. Prima Abdika: Jurnal Pengabdian Masyarakat, 2(1), 90-95. https://doi.org/10.37478/abdika.v2i1.1709

Copyright (c) 2022 Narita Yuri Adrianingsih, Jeni Marianti Loban, Landerius Maro, Lory Fitriana Ur Dollu. This work is licensed under a Creative Commons Attribution-ShareAlike 4.0 International License.

\section{Pendahuluan}

Matematika sangatlah penting digunakan dalam kehidupan sehari-hari di berbagai bidang ilmu. Dalam pengembangan matematika diperlukan strategi yang tepat. Tetapi dalam kenyataannya matematika merupakan mata pelajaran yang sulit, tidak menyenangkan (Seruni et al., 2019), dan banyak memperdayakan (Surya, 2012). Oleh karena itu, kemampuan matematika pada setiap siswa masih rendah. Apabila kemampuan matematika rendah, maka kualitas belajar akan terpengaruh dan berdampak pada prestasi siswa (Sulistyaningsih et al., 2012).

Pendidikan berperan penting dalam kehidupan manusia. Manusia pun menjadi lebih terarah dalam hidup apabila ada pendidikan dalam kehidupannya. Pendidikan pun berguna untuk penyelesaian masalah dalam kehidupan sehari-hari (Siagian, 2016). Dalam bidang pendidikan diperlukan peningkatan daya saing siswa yang dilakukan dengan cara meningkatkan dan mengembangkan kreatifitas, kemandirian, dan inovatif siswa yang dilakukan melalui mata pelajaran, media pembelajaran, buku pelajaran, dan lingkungan terutama dalam mata pelajaran matematika (Umam, 2018; Yana \& Sari, 
2021). Pembelajaran merupakan aktifitas interaksi antara siswa dengan guru. Pembelajaran yang tertutup dan monoton bukanlah fokus pembelajaran matematika tetapi pembelajaran yang matematis dan sistematis yang dibutuhkan (Novitasari, 2016). Di dalam pembelajaran mata pelajaran matematika pada jaman sekarang, dibutuhkan teknologi untuk meningkatkan kreatifitas siswa dan supaya siswa lebih termotivasi untuk belajar matematika. Namun, masih terdapat sekolah yang masih belum mengenalkan teknologi terutama di daerah pinggiran terkhususnya di SMP Negeri Mainang.

Pada mata pelajaran matematika terdapat beberapa ilmu yang diajarkan yaitu salah satunya statistika. Statistika merupakan metode yang mempelajari bagaimana mengumpulkan, mampresentasikan, menganalisa data, dan menginterpretasikan data (Sukestiyarno, 2014). Statistika menurut tujuannya terdapat 2 macam yaitu statistika deskriptif dan statistika inferensia. Statistika deskriptif bertujuan untuk mendeskripsikan atau menggambarkan data (Junaidi, 2015) dan merupakan cara mengumpulkan data dan penyajian data supaya mudah dimengerti (Nasution, 2017). Salah satu metode dalam statistika untuk menyajikan data adalah dengan menggunakan diagram. Adapun diagram yang umumnya digunakan terutama dalam proses belajar mengajar di sekolah menengah adalah diagram garis, diagram batang, dan diagram lingkaran. Dengan menggunakan diagram ini, data dapat dipahami dengan baik dibandingkan dengan menggunakan tabel. Apalagi jika menggunakan teknologi, untuk menggambarkan diagramdiagram ini lebih efisien dan lebih tepat. Aplikasi yang digunakan dalam pembelajaran ini adalah dengan menggunakan Microsoft Excel.

Berdasarkan analisis situasi yang terjadi di SMP Negeri Mainang dalam belajar mengajar masih kurang maksimal terutama dalam mata pelajaran matematika. Materi yang didapatkan juga masih belum maksimal karena masih belum memadai teknologi, yaitu belum ada komputer. Dalam belajar mengajarpun tidak begitu optimal.

Oleh karena itu, penulis melakukan strategi dalam belajar statistika untuk membuat diagram, yang merupakan salah satu materi yang ada di mata pelajaran matematika, siswa perlu diajarkan untuk menyajikan data yaitu dengan membuat diagram kemudian diajarkan dengan hal baru dengan menggunakan teknologi yaitu mengoperasikan laptop dengan menggunakan Microsoft Excel supaya lebih mudah dan dalam belajar lebih menyenangkan. Kemudian siswa dapat lebih terbiasa menggunakan teknologi.

\section{Metode Pelaksanaan}

Metode pelaksanaan kegiatan ini dibagi menjadi 3 tahapan yaitu:

1) Tahap Persiapan

Pada tahap ini dilakukan survey terlebih dahulu ke tempat yang akan digunakan untuk pengabdian, kemudian dilakukan penyiapan materi yang akan disampaikan saat pembelajaran pembuatan diagram dengan Microsoft Excel.

2) Tahap pelaksanaan

Tahap pelaksanaan dilakukanlah pelatihan tentang pembuatan diagram dengan Microsoft Excel kepada siswa/i SMP Negeri Mainang. Sebelum langsung praktek Microsoft Excel, siswa/i diajarkan materi 
tentang statistika dasar yaitu tentang data dan bagaimana dari data dibuat untuk menjadi diagram.

3) Tahap Evaluasi

Tahap ini, siswa/i saling berlomba untuk mengerjakan latihan sampai selesai, dan bagi kelompok yang lebih dahulu mendapatkan hadiah, karena dapat menyelesaikan latihan dengan baik dan benar.

Kegiatan pengabdian kepada masyarakat ini dilakukan pada tanggal 15 Oktober 2021. Jumlah partisipan yang mengikuti pelatihan ini sebanyak 15 siswa. Tempat kegiatan di SMP Negeri Mainang, Kalabahi, Alor.

\section{Hasil dan Pembahasan}

Pelaksanaan kegiatan pengabdian pelatihan diagram yang dilakukan di SMP Mainang dihadiri oleh 15 siswa. Berdasarkan survey yang dilakukan, di SMP Mainang, sarana untuk belajar sangatlah kurang, karena belum didukung teknologi, sehingga siswa/i-nya masih belum mengerti tentang bagaimana mengoperasikan laptop. Mereka masih membutuhkan dukungan dari pemerintah untuk mendukung pembelajaran di SMP Mainang supaya dapat mencapai pembelajaran di era saat ini yaitu maju dalam teknologi. Kemudian dalam masalah materi, siswa/i masih belum belajar tentang statistika dasar, yaitu tentang data dan pembuatan diagram. Oleh karena itu, dilakukanlah pengabdian untuk siswa/i SMP Mainang dengan pelatihan statistika dasar yaitun menyajikan data dalam bentuk diagram batang, lingkaran, dan garis dengan menggunakan Microsoft Excel, dan mempersiapkan 3 laptop untuk mereka dapat mengikuti pelatihan ini.

Pada tahap persiapan, penulis melakukan survey terlebih dahulu, apa yang menjadi akar permasalahan dalam belajar matematika. Kemudian penulis menyiapkan materi tentang statistika yaitu dimulai dari pengertian data, populasi, sampel, dsb, kemudian menyajikan data dengan membuat diagram, yaitu diagram batang, lingkaran, dan garis. Setelah itu dilanjutkan materi tentang praktikum untuk membuat diagram dengan menggunakan Microsoft Excel.

Pada tahap pelaksanaan, pelatihan hanya dilakukan selama sehari saja. Pengabdian ini dilakukan tim, yaitu ada 3 orang, 2 orang membantu dalam pelatihan ini dan yang 1 orang menjelaskan materi dan praktik bagaimana pengoperasian komputer sebagaimana seperti seorang guru. Dalam penyajian diagram dibutuhkan sekumpulan data. Pengambilan data yang digunakan sebagai pelatihan dan praktikum adalah dari siswa/i sendiri, yaitu dengan memberikan pertanyaan hobi mereka masing-masing, yaitu ada yang hobi menyanyi, mendengarkan musik, membaca, dan menari. Sehingga data yang didapatkan dari hobi mereka adalah 5 siswa hobi menyanyi, 3 siswa hobi mendengarkan musik, 4 orang hobi membaca, dan sisanya yaitu hobi menari. Setelah didapatkan data tentang hobi siswa tersebut, pelatih mengajarkan bagaimana menyajikan data dengan menggunakan diagram. Kemudian diajarkan cara penyajian dengan menggunakan Microsoft Excel. Adapun langkah-langkahnya adalah sebagai berikut:

1. Buka Microsoft Excel dengan lambang X hijau.

2. Klik blank workbook. 
>> Kepala grafik berfungsi untuk menentukan label setiap segmen data dan harus ditempatkan di baris teratas lembar lajur (spreadsheet). Anda bisa mulai menambahkan kepala pada kotak "C2", kemudian dilanjutkan kotak sebelah kanannya

>> Label yang memisahkan baris-baris data perlu ditambahkan pada kolom "B" (mulai dari kotak "B3") dilanjutkan ke baris bawahnya.(digunakan sebagai label grafik)

\section{>> Masukkan data grafik}

3. Pilih data untuk grafik yang akan dibuat. Klik dan seret kursor dari pojok kiri atas kelompok data (mis. kotak "A1") ke arah pojok kanan bawah. Pastikan Anda ikut menyertakan baris kepala dan kolom label.

4. Klik tab "Insert" pada bagian jendela Excel.

5. Pilihlah jenis grafik pada segmen "Charts", pilih jenis grafik yang ingin digunakan.

6. Tambahkan judul pada grafik. Klik dua kali di kolom "Chart Title" yang ada di bagian atas grafik, kemudian hapus teks "Chart Title" dan ganti dengan judul sendiri.

Berikut adalah contoh gambar diagram-diagramnya:

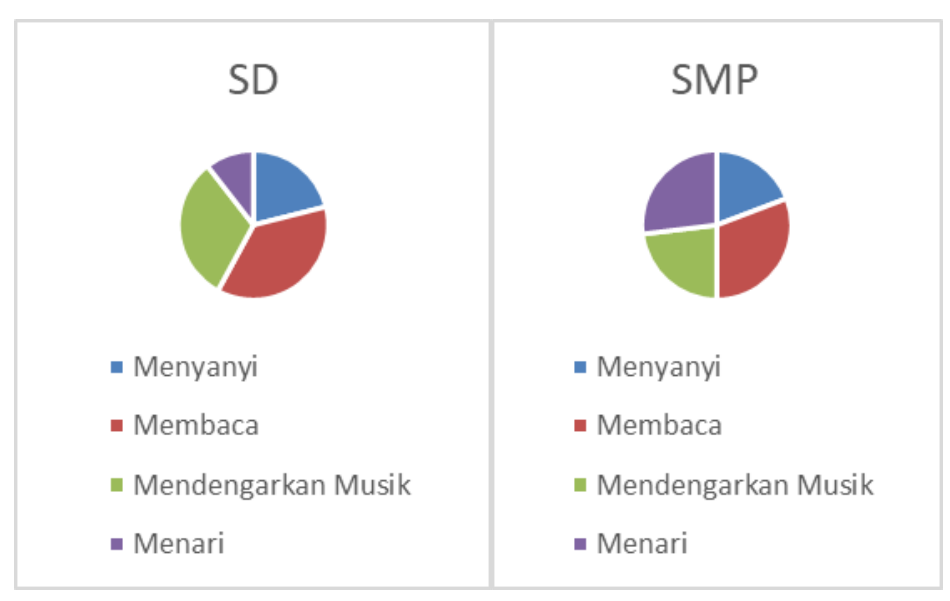

Gambar 1. Diagram lingkaran

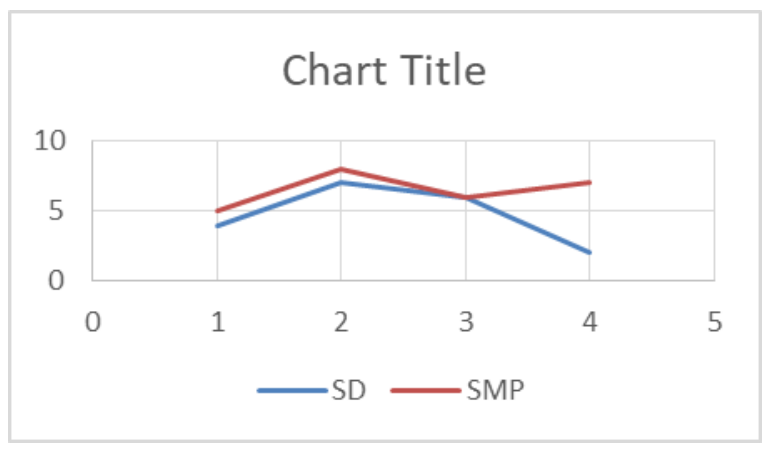

Gambar 2. Diagram garis 


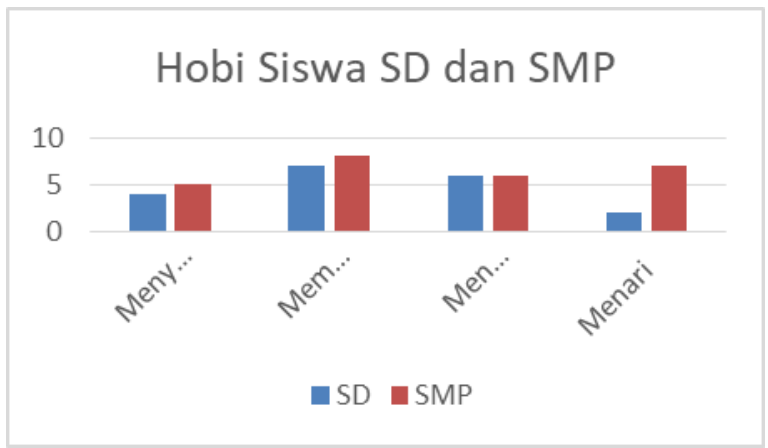

Gambar 3. Diagram batang

Pada tahap evaluasi, anak-anak diminta untuk mengerjakan latihan praktikum, yaitu dengan diberikan data kemudian praktik secara kelompok. Apabila salah satu kelompok sudah menyelesaikan dengan benar maka kelompok tersebut mendapatkan hadiah. Dan mereka sangat antusias dalam mengerjakannya, tiap kelompok dapat menyelesaikan dengan benar dan satu kelompok yang menyelesaikan dengan cepat dan benar.

Kegiatan pengabdian ini dinilai mampu menumbuhkan semangat siswa/i SMP Mainang dikarenakan siswa/i mendapatkan materi baru yang didukung dengan menggunakan teknologi dan mereka sangat antusias dalam belajar. Berikut adalah salah satu foto-foto pelaksanaan kegiatan Pengabdian:

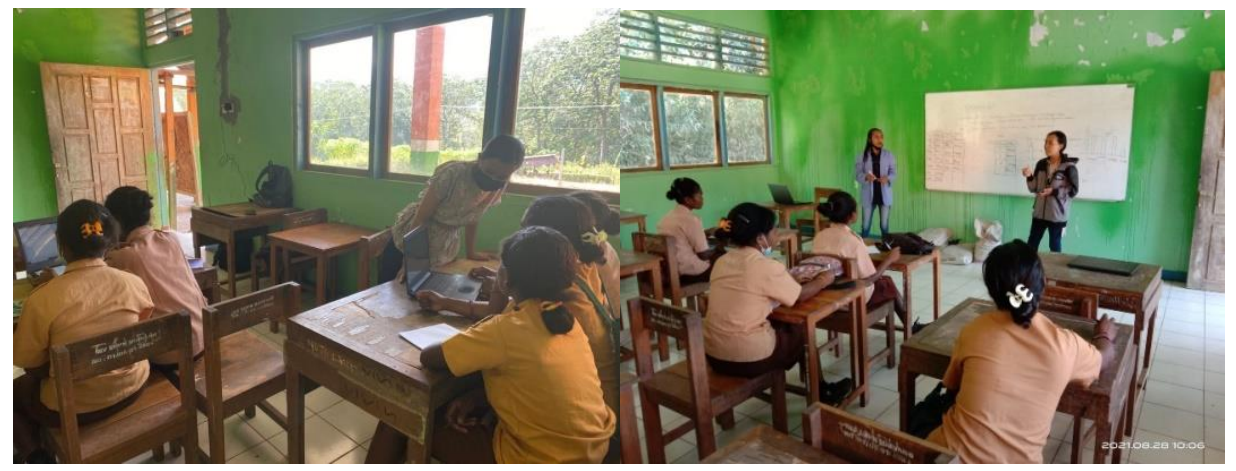

Gambar 4. Foto-foto Pelaksanaan Pengabdian

\section{Simpulan dan Tindak Lanjut}

Pembelajaran dalam pembuatan diagram dengan Microsoft Excel sangatlah membantu siswa dalam belajar penyajian data dengan mudah, lebih aktif dan lebih menyenangkan. Dengan adanya teknologi yang menunjang, siswa dapat lebih berkreasi dan berinovasi lagi. Kegiatan ini juga dapat menumbuhkan semangat kepada siswa untuk lebih menyukai matematika terutama statistika. Kedepannya, diharapkan siswa/i SMP Mainang dapat dukungan teknologi oleh pemerintah, supaya dapat mendukung kegiatan belajar mengajar, dan dapat siswa lebih kreatif dan inovatif lagi.

\section{Daftar Pustaka}

Nasution, L. M. (2017). Statistik deskriptif. Hikmah, 14(1), 49-55.

Junaidi, J., \& Jambi, U. (2015). Statistik Deskriptif dengan Microsoft Office Excel. June. https://doi.org/10.13140/RG.2.1.1297.4248 
Novitasari, D. (2016). Pengaruh Penggunaan Multimedia Interaktif Terhadap Kemampuan Pemahaman Konsep Matematis Siswa. FIBONACCI: Jurnal Pendidikan Matematika Dan Matematika, 2(2), 8. https://doi.org/10.24853/fbc.2.2.8-18

Seruni, S., Mulyatna, F., \& Nurrahmah, A. (2019). Pkm Inovasi Pembelajaran Matematika Sd/Mi Melalui Permainan Ular Tangga. SELAPARANG Jurnal $\begin{array}{llll}\text { Pengabdian Masyarakat Berkemajuan, } & 75 .\end{array}$ https://doi.org/10.31764/jpmb.v3i1.1128

Siagian, M. D. (2016). KEMAMPUAN KONEKSI MATEMATIK DALAM PEMBELAJARAN MATEMATIKA. MES, 2, 58-67.

Sukestiyarno. (2014). Statistika Dasar (A. Pramesta (ed.); 1st ed.). Andi.

Sulistyaningsih, D., Waluya, S. B., \& Kartono. (2012). MODEL PEMBELAJARAN KOOPERATIF TIPE CIRC DENGAN PENDEKATAN KONSTRUKTIVISME UNTUK MENINGKATKAN KEMAMPUAN KONEKSI MATEMATIK. Unnes Journal of Mathematics Education Research, 1(2).

Surya, E. (2012). Visual thinking, mathematical problem solving and selfregulated learning with contextual teaching and learning approach edy surya. Jurnal Penelitian Dan Pembelajaran Matematika, 5, 41-50.

Umam, K. (2018). PENINGKATAN KEMAMPUAN BERPIKIR KRITIS MATEMATIS SISWA MELALUI PEMBELAJARAN RECIPROCAL TEACHING. Jurnal Pendidikan Matematika Indonesia, 3, 57-61. https://journal.stkipsingkawang.ac.id/index.php/JPMI/article/view/807 $/ \mathrm{pdf}$

Yana, Y., \& Sari, D. P. (2021). Investigasi Minat Dan Motivasi Belajar Matematika Siswa Di Era Covid-19. Statmat: Jurnal Statistika Dan Matematika, 3(1), 19. https://doi.org/10.32493/sm.v3i1.8184 